\title{
Lack of TEK Gene Mutation in Patients with Cutaneomucosal Venous Malformations from the North-Western Region of Algeria
}

\author{
Nabila Brahami, ${ }^{1}$ Mourad Aribi, ${ }^{1}$ Badr-Eddine Sari, ${ }^{1,2}$ Philippe Khau Van Kien, ${ }^{3}$ \\ Isabelle Touitou, ${ }^{4,5,6}$ Gérard Lefranc, ${ }^{7}$ and Mouna Barat-Houari ${ }^{4}$ \\ ${ }^{1}$ Laboratory of Applied Molecular Biology and Immunology, University of Tlemcen, 13000 Tlemcen, Algeria \\ ${ }^{2}$ Service de Stomatologie et de Chirurgie Buccale du Centre Hospitalier et Universitaire de Tlemcen, 13000 Tlemcen, Algeria \\ ${ }^{3}$ Génétique Médicale, Laboratoire de Cytologie Clinique et Cytogénétique, CHU de Nîmes, Place du Professeur Robert Debré, \\ 30029 Nimes Cedex 9, France \\ ${ }^{4}$ Unité Médicale des Maladies Auto-Inflammatoires, Département de Génétique, CHRU, Montpellier, \\ 34961 Montpellier Cedex 2, France \\ ${ }^{5}$ Université Montpellier 1, 34961 Montpellier Cedex 2, France \\ ${ }^{6}$ Génétique des Maladies Auto-Inflammatoires et des Ostéo-Arthropathies Chroniques, INSERM U844, \\ 34091 Montpellier Cedex 5, France \\ ${ }^{7}$ Laboratoire d'Immunogénétique Moléculaire, Institut de Génétique Humaine, CNRS UPR 1142, \\ et Université Montpellier 2, 34095 Montpellier Cedex 5, France
}

Correspondence should be addressed to Mourad Aribi; m_aribi@mail.univ-tlemcen.dz

Received 2 August 2013; Accepted 21 October 2013

Academic Editor: Biaoru Li

Copyright (C) 2013 Nabila Brahami et al. This is an open access article distributed under the Creative Commons Attribution License, which permits unrestricted use, distribution, and reproduction in any medium, provided the original work is properly cited.

Background. Venous malformations (VM) result from an error in vascular morphogenesis. The first gene suspected in their development is the TEK gene (tyrosine kinase, endothelial). Mutations of this gene have been identified in several Belgian families with a dominant form of the disease. Therefore, we investigated whether mutations in this TEK gene could explain the MV development in patients of families from Tlemcen region (north-western Algeria). Methods. Genomic DNA was extracted from leucocytes of ten patients. The search for mutations in all the 23 exons and in the $5^{\prime}$ and $3^{\prime}$ intronic sequences flanking the TEK gene was performed using PCR amplification and direct sequencing of amplified genomic DNA. Additionally, a search for somatic mutations of the gene TEK was performed on a biopsy of the venous malformation from one of the ten eligible patients. Results. The sequencing of the 23 exons of the TEK gene revealed neither germinal mutation in our ten patients nor somatic mutation in the tissue of the biopsy. Conclusion. The absence of mutation in the TEK gene in the population studied suggests that the TEK gene is not necessarily involved in the onset of VM; its association with these malformations may differ from one population to another.

\section{Introduction}

Vascular malformations (VM) are benign vascular lesions that are described as structural congenital anomalies [1]. These lesions are always present at birth, but may not be visible until days, weeks, or even years after birth [2]. VM are classified according to the type of involved vessels, such as arterial, venous, lymphatic, capillary malformations, or a combination of different vessels [1-3].
VM result from an error in vascular morphogenesis [4]. They are present at birth and their growth is usually gradual and steady during the first year of life [3]. Their evolutionary peak is generally observed in adolescence or after a traumatic event [5]. Localized facial forms are present essentially on the lips, eyelids, and tongue $[5,6]$. The extension of the gingival mucosa can result in bleeding, which can occur spontaneously and/or after certain dental procedures and treatments [7]. 
Some locations cause, by mass effect, skeletal deformities in the frontoorbital region with enophthalmos and maxillomandibular and dentoalveolar defects, with repercussions on the dental bite and open bite $[5,8]$. An important lip deformity tends to make them incompetent. Likewise, giant VM of the tongue can cause permanent changes in normal dental occlusion [7, 8]. Additionally, superficial VM can lead to disfigurement, resulting in an asymmetry hardly supported by patients $[9,10]$. This condition is often the cause of low selfesteem and school failure in children and adolescents.

Although the real causes of the development of VM are still poorly understood, previous studies have suggested the involvement of genetic factors in their occurrence [11]. First, the TEK gene (also called TIE-2, tyrosine kinase with immunoglobulin and epidermal growth factor homology domain 2), located at chromosomal region 9 p21 and encoding the endothelial-specific receptor tyrosine kinase, has been implicated in Belgian families with a dominant form of the disease $[11,12]$.

To date, seven missense mutations were identified in these Belgian patients with dominant transmission, including $2545 \mathrm{C}>\mathrm{T}$ in exon $15,2690 \mathrm{~A}>\mathrm{G}, 2744 \mathrm{G}>\mathrm{A}, 2752 \mathrm{C}>\mathrm{T}$, $2755 \mathrm{G}>\mathrm{T}$, and $2773 \mathrm{G}>\mathrm{T}$ in exon 17 , and $3300 \mathrm{G}>\mathrm{C}$ in exon 22 $[11,13,14]$. These mutations lead to an excess of angiopoietin 1 signaling, a ligand for TIE-2 receptor, and consequently to an abnormal proliferation of endothelial cells [11].

The relatively high frequency of VM in Tlemcen region (north-western Algeria) compared to others [15] led us to search in all exons of the TEK gene for either already described mutations or other not yet identified.

\section{Materials and Methods}

2.1. Patients and Families. A total of ten (10) families, each with a patient with VM (3 men and 7 women), were recruited in Stomatology and Oral Surgery Department of Tlemcen University Medical Centre (Figure 1).

The characteristics of the patients and family members were recorded using a detailed questionnaire. The mean age ( \pm standard error) of the patients at diagnosis was $12 \pm 1$ years. The recruitment of the patients was carried out on the basis of clinical examination. Such malformations are characterized by a soft, compressible, nonpulsatile tissue mass that does swell in inclined or proclive position $[6,16]$ (Figure 2).

A magnetic resonance imaging (MRI) was performed in the case of malformations that are simultaneously superficial and deep (Figure 3). The main inclusion criteria were the geographical location of patients exclusively in the region of Tlemcen and inactive malformations. The exclusion criteria were especially arteriovenous malformations. All participants or their parents or guardians have signed an informed consent in accordance with the latest version of the Helsinki Declaration. This study was approved by the Local Ethics Committee and supported by the Hubert Curien Partnership (PHC Tassili, Code 10MDU794).

2.2. Samples. A total of 52 blood samples were collected into EDTA-containing Vacutainer tubes (BD Vacutainer EDTA,
USA). VM tissues were taken from one patient after surgery (VMF03.III.2/family VMF03), immediately placed into a sterile collection tube in liquid nitrogen and, then, stored at $-80^{\circ} \mathrm{C}$ in dry ice.

2.3. DNA Analysis. For all samples, DNA was extracted from blood cells using QIAamp DNA Blood Midi Kit Qiagen, as recommended by the manufacturer (Qiagen Valencia, CA, USA). The tissue DNA was isolated using spin columns with the QIAamp DNA Blood Mini Kit Qiagen. The DNA concentration was then measured by spectrophotometer NanoDrop ND-1000 at $260 \mathrm{~nm}$ and then at $280 \mathrm{~nm}$ (NanoDrop Technologies, Wilmington, DE).

The search for mutations in all the 23 exons as well as in the $5^{\prime}$ and $3^{\prime}$ intronic sequences flanking the exons of the TEK gene was performed by PCR amplification followed by direct sequencing of amplified DNA segments. Such analyses were performed in the Genetics Laboratory of the Medical Unit for Auto-Inflammatory diseases, Hospital Arnaud de Villeneuve, Montpellier, France.

The primer sequences were specifically established to amplify each exon (Table 1), using the Primer3 program [17] (v.0.4.0), referring to the TEK gene sequence (ENSG00000120156) published in Ensembl [18].

The DNA was amplified in a thermocycler for PCR (Applied Biosystems, Foster, CA), using the primers described in Table 1. The medium of the DNA amplification reaction was composed of $50 \mathrm{ng}$ of DNA, $25 \mu \mathrm{M}$ of each primer, and $2 \mathrm{X}$ Promega PCR Master Mix (Promega). The PCR conditions were as follows: 5 minutes at $95^{\circ} \mathrm{C}$ followed by 35 cycles of 30 seconds of denaturation at $95^{\circ} \mathrm{C}$, primer annealing at $60^{\circ} \mathrm{C}$ for 30 seconds, and elongation at $72^{\circ} \mathrm{C}$ followed by one cycle at $72^{\circ} \mathrm{C}$ for 10 minutes.

After checking the quality and size of the PCR products by agarose gel (1.5\%) electrophoresis, a bidirectional sequencing was performed. The amplification products were bidirectionally sequenced with Mix BigDye Terminator kit version 3.1 (ABI). The sequences of the 23 exons and their flanking regions were compared with the TEK gene reference sequence published in Ensembl [18], using the SeqScape v2.5 software $(\mathrm{ABI})$.

\section{Results}

3.1. Phenotype of Patients. Table 2 shows the clinical data of eleven patients with VM, ten of which had a lip malformation and one had a genio-cervical malformation (one of the eleven patients was not included in the molecular study). Eight patients are female; one of the ten families (VMF04) accounts for two patients with venous malformation (Figure 1).

3.2. Molecular Analysis of the TEK Gene. The amplification fragments were obtained for each of the 23 exons of the TEK gene, using DNA from blood samples of ten patients and VM lip tissues from one patient (VMF03.III.2) after surgery. Figure 4 shows the amplification fragments of exon 17 from genomic DNA of the ten patients included in this study and from somatic DNA of patient VMF03.III.2. 


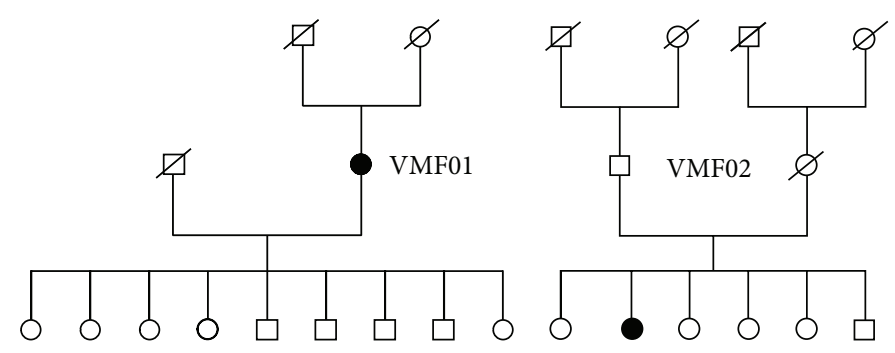

(a)

(b)

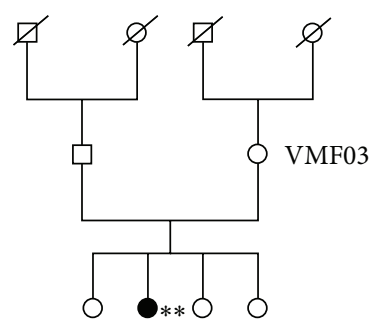

(c)

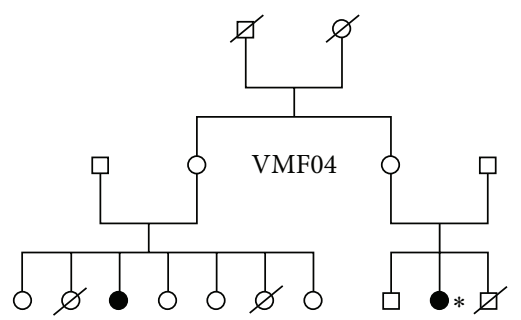

(d)

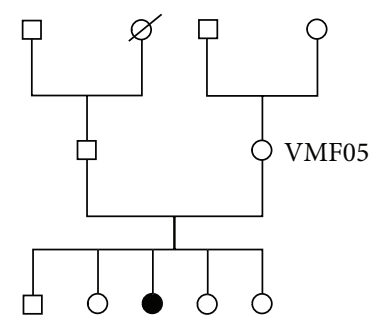

(e)

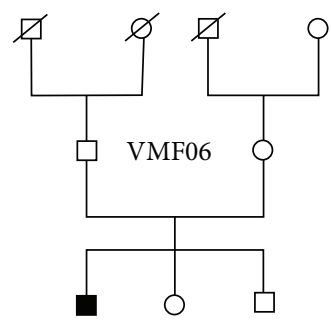

(f)

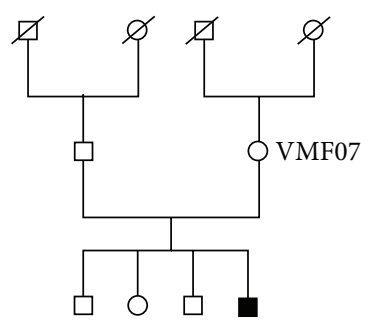

(g)

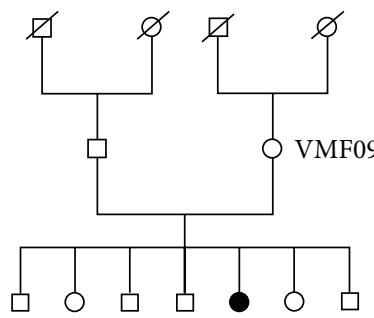

(i)

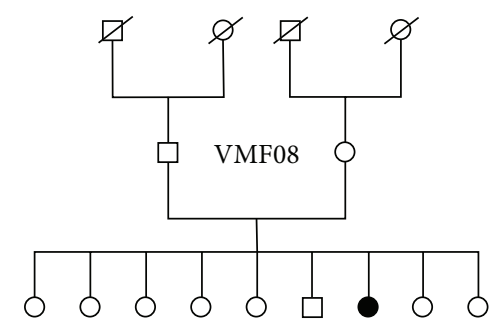

(h)

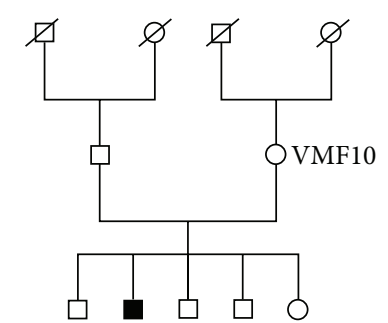

(j)

FIGURE 1: Genealogical trees of ten Algerian families analyzed for TEK gene. ${ }^{*}$ Patient VMF04.III.3 not included in the molecular study. ${ }^{* *}$ For patient VMF03.III.2, the DNA in the tissue of the biopsy was sequenced.

None of the mutations previously described, including even the mutation of the CGG codon $849(2545 \mathrm{C}>\mathrm{T})$ in exon 15 , reported by Wouters et al. [13], in six out of twelve Belgian families with a hereditary form of VM, has been detected after ten blood and one VM tissue DNA analyses of all the 23 exons of the TEK gene (Figure 5).

\section{Discussion}

In this study, we present the results of the TEK gene sequencing in ten unrelated patients from Tlemcen in the northwestern region of Algeria with VM.

According to the previous analyses for different mutations in the germline DNA [11, 13, 14], we have to firstly look 


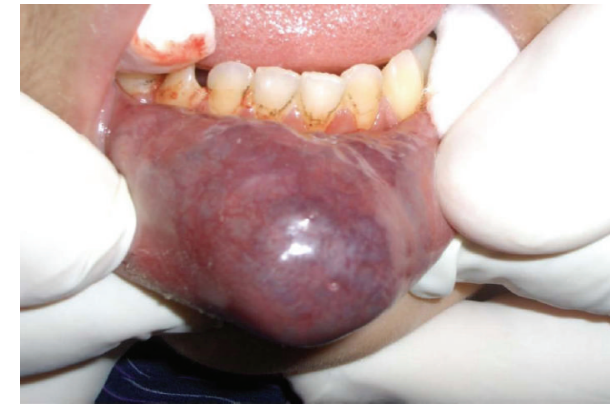

(a)

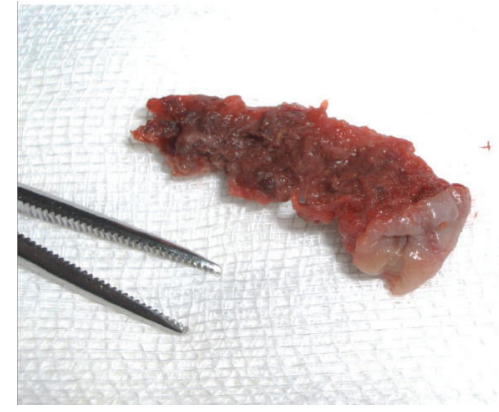

(b)

FIgURE 2: Aspect of the labial venous malformation seen after inclined position and surgical fragment collected following resection using multiple times of transmucosal embolization.

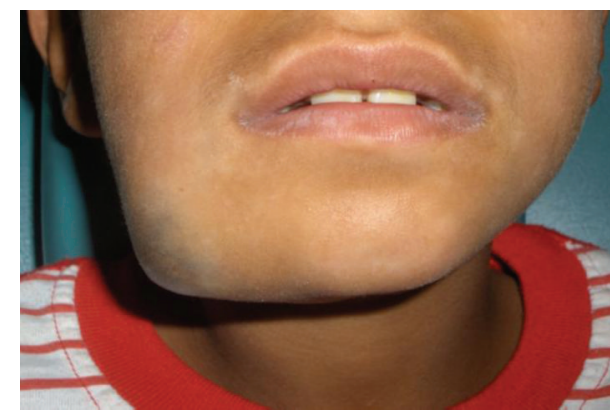

(a)

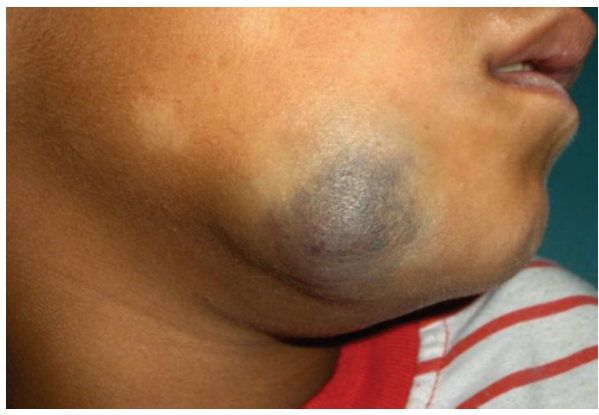

(c)

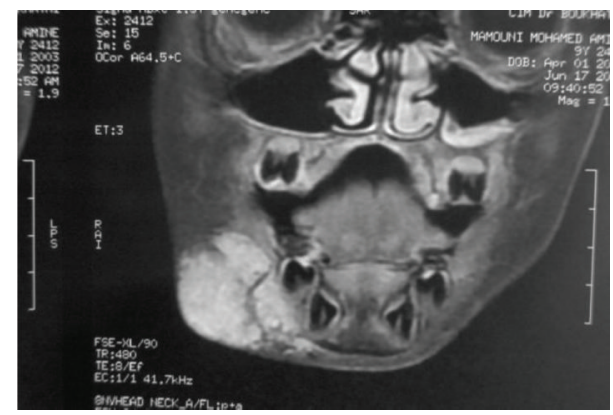

(b)

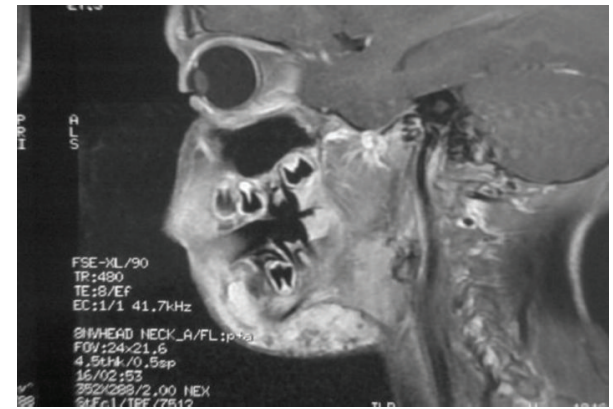

(d)

FIGURE 3: A magnetic resonance imaging (MRI) of superficial and deep venous malformation. The technique was performed in three planes with T2 fat-saturation (T2-FS), axial T1, 2D time-of-flight (2D TOF), magnetic resonance angiography (MRA) of supra-arterial trunks, and three planes T1-FS for the cervical region.

for these mutations, and, then, we extended analyses to all the 23 exons of the TEK gene. Since no germinal mutation was found in all the samples, we searched for somatic mutations in tissues of a VM biopsy.

The lack of mutation suggests that there is a mutated gene other than TEK or other factors which would be involved and responsible for VM development in our population.

The vascular endothelial cell (EC) specific receptor tyrosine kinase TEK plays a crucial role in angiogenesis and cardiovascular development [19-27]. Its ligands, the angiopoietins (Ang), induce receptor dimerization and phosphorylation [28], with Ang-1 acting as an agonist and Ang-2 as context-dependent antagonist or weak agonist $[29,30]$.
Other mutation players within the TEK pathway, especially those proximal to the receptor, could also be expected to yield similar, specific phenotypes. These include TIE-1, which can heterodimerise with TEK [31, 32]; the Ang ligands [29$35]$; and the vascular endothelial protein tyrosine phosphatase (VE-PTP), which can specifically regulate TEK activation $[36,37]$.

Ang-1 stimulation of TEK has recently been found to induce the expression of Apelin, a ligand for the G-proteincoupled receptor (GPCR, also known as the APJ receptor), in ECs. This system in turn regulates the caliber of blood vessels [38] making it an attractive, as yet untested, candidate pathway through which the dilated channels in VM may occur. 
TABLE 1: Primer sequences of all the exons of the TEK gene.

\begin{tabular}{|c|c|c|c|}
\hline Exon & Amorce sens $\left(5^{\prime}-3^{\prime}\right)$ & Amorce antisens $\left(5^{\prime}-3^{\prime}\right)$ & PCR product \\
\hline Exon1.1 & AGTCTGAGAAGGATTGGTCATCA & CTGTCTGAGCACAGGGAGTTT & $333 \mathrm{bp}$ \\
\hline Exon1.2 & CAGCCCTGCTGATACCAAAT & CACTGATGAGATTTGGGGAGA & $409 \mathrm{bp}$ \\
\hline Exon2 & GTTTACCCAATGGGGTCATG & AGCAGCTGCCAAGACAAAAG & $448 \mathrm{bp}$ \\
\hline Exon3 & AACGCATTAGCCACCACTGT & ACATCTGCCCACAAGACCA & $360 \mathrm{bp}$ \\
\hline Exon 4 & CTGAATAGTTCAGCATTTTCATTCT & CAATGCCTGGTTTTTGCTTA & $422 \mathrm{bp}$ \\
\hline Exon5 & CTCCTTGTCTTTGTTTCTGTCG & AAATTCTAGATCCAGCAACGATG & $399 \mathrm{bp}$ \\
\hline Exon6 & GTTCATCCTACCATGCCACA & TGATTCAAAATCCTGTTGTCCA & $413 \mathrm{bp}$ \\
\hline Exon7 & AGTTGGCATGATAGGAGCTCA & GGATGGAAACAAAAGAGGCTT & $453 \mathrm{bp}$ \\
\hline Exon8 & TCATCCACATCACAGGTGTCT & GTCAGTTCTGCCTCTCCAGG & $469 \mathrm{bp}$ \\
\hline Exon9 & TGGGGTCAATGTTATGGACC & TCCTGGAAATTACCCCAAAG & $335 \mathrm{bp}$ \\
\hline Exon10 & ATCACAAAACCTCAAAGCCG & AGCCACCACCTTGAGGTAGA & $331 \mathrm{bp}$ \\
\hline Exon11 & TTTCAAAAGCCTAATTTTCCTCA & CACCCATTCAAAAGCGAACT & $462 \mathrm{bp}$ \\
\hline Exon12.1 & AGTTGGCATGATAGGAGCTCA & GGATGGAAACAAAAGAGGCTT & $453 \mathrm{bp}$ \\
\hline Exon 12.2 & TGGGGTCAATGTTATGGACC & TCCTGGAAATTACCCCAAAG & $335 \mathrm{bp}$ \\
\hline Exon13 & GCATAATGATCTAGGCCATGG & CCTATAGGGCTGCACGGTAA & $413 \mathrm{bp}$ \\
\hline Exon14 & GCTGCTGTTAAGTTCCCATTACA & AAGCCAAAGAGAAGATGAGGC & $397 \mathrm{bp}$ \\
\hline Exon15 & GTTCATCCTACCATGCCACA & TGATTCAAAATCCTGTTGTCCA & $413 \mathrm{bp}$ \\
\hline Exon16 & TTTGGTTGTATACAGTTGATGGTGA & AGGCAAACCACAGCACAGTC & $404 \mathrm{bp}$ \\
\hline Exon17 & GTTTACCCAATGGGGTCATG & AGCAGCTGCCAAGACAAAAG & $448 \mathrm{bp}$ \\
\hline Exon18 & TCTTCTGCCAAGATGTGGTG & CAGGGGAGTACCTCGGAAA & $358 \mathrm{bp}$ \\
\hline Exon19 & CTACCCAGCAATCATTTGTGG & TGCTAATTTATTTCCTGAGCTTTTT & $310 \mathrm{bp}$ \\
\hline Exon 20 & GTGCAAGGGCCTATCCTAGG & CCAAGTCACATCTGGTAGAACCA & $304 \mathrm{bp}$ \\
\hline Exon21 & ATGTGCAGTGAGTTTGCCAA & CGGCTGACTTTGCTAGAGTC & $338 \mathrm{bp}$ \\
\hline Exon22 & GTTTACCCAATGGGGTCATG & AGCAGCTGCCAAGACAAAAG & $448 \mathrm{bp}$ \\
\hline Exon23.1 & AGGTGGAATCAAAGCAGCCT & CACGCCTTCCTATGAAGTCC & $414 \mathrm{bp}$ \\
\hline Exon 23.2 & AATCAGAATGCCTGTTTGTGG & TTCTTAGGCTTGTAAGCAATGAG & $452 \mathrm{bp}$ \\
\hline $3^{\prime} \mathrm{UTR}$ region & TCTCAАТTTТАТСССТСАССТG & TAAAGTATAATAAGGACATGTGGCA & $472 \mathrm{bp}$ \\
\hline
\end{tabular}

bp: base pair.

$3^{\prime}$ UTR: $3^{\prime}$ untranslated region.

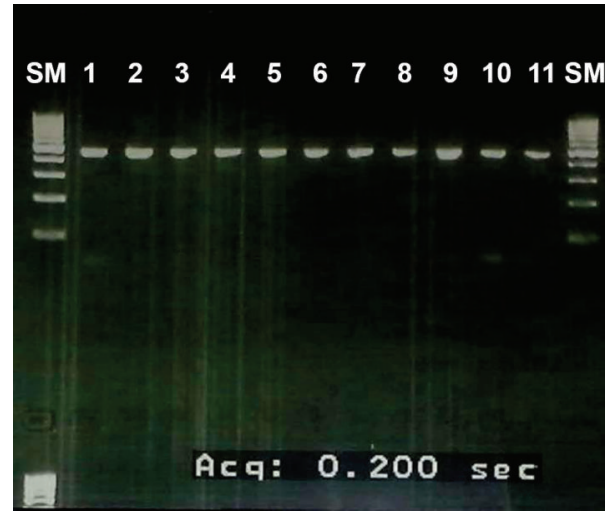

Figure 4: Amplified fragments detected on 1.5\% agarose gel electrophoresis of exon 17 for DNA from blood cells (lanes 1 to 10) and tissue of the biopsy (lane 11) of patients with venous malformation. Lane SM: 100 base-pair ladder (size markers).

Venous anomalies represent a significant fraction of patients seen at centers specialized in treating VM, as they can

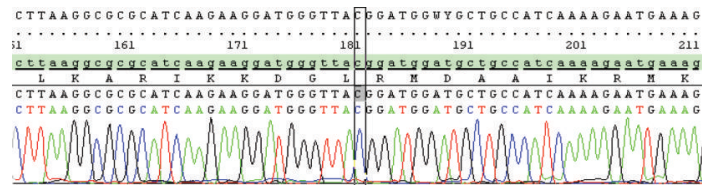

FIGURE 5: Result of direct sequencing of codon 849 of exon 15 in all the studied patients with venous malformation.

cause pain and affect appearance or organ function, due to their size, localization, and expansion.

The majority of VM are sporadic in nature and characterized by extensive, unifocal lesions of variable size, which can infiltrate deep into underlying tissues.

The search for mutations in other candidate genes (ANG1, ANG2, TIE1, VE-PTP [vascular endothelial protein tyrosine phosphatase] and the APLN genes) in the DNA from biopsies is the next step. If this proves unsuccessful, it will be necessary to achieve exome sequencing analysis, or whole genome sequencing, and to compare the sequences with those of exons and the entire genome of germline DNA from leukocytes of corresponding patient. 
TABLE 2: Descriptions of patients with venous malformation.

\begin{tabular}{lccccc}
\hline Family & Patient symbol & Gender & Number of lesions & Location & Other patients in family \\
\hline VMF01 & VMF01.II.2 & F & 1 & Lip & No \\
VMF02 & VMF02.III.2 & F & 1 & Lip & Lip \\
VMF03 & VMF03.III.2 & F & 1 & Lip & Yes \\
VMF04 & VMF04.III.3 & F & 1 & Lip & Yes \\
VMF04 & VMF04.III.9 & F & 1 & Lip & Lo \\
VMF05 & VMF05.III.3 & F & 1 & Genio-cervical & No \\
VMF06 & VMF06.III.1 & M & 1 & Lip & No \\
VMF07 & VMF07.III.4 & M & 1 & Lip & No \\
VMF08 & VMF08.III.7 & F & 1 & Lip & No \\
VMF09 & VMF09.III.5 & F & 1 & 1 & M \\
VMF10 & VMF10.III.2 & & & & No \\
\hline
\end{tabular}

F: female; M: male.

\section{Conclusions}

The absence of mutation in the TEK gene in the population studied suggests that the TEK gene is not necessarily and not the sole gene involved in the onset of VM. It will be interesting to search on other mutated gene(s) responsible for the development of these malformations on much more patients. The exome sequencing should greatly help to unmask the other involved gene(s), which will be validated only after a study of random samples of the Tlemcen population, in order to ensure that it is not a neutral polymorphism, and that the mutation(s) is or are not found in healthy subjects. If so, the knowledge of the molecular and cellular dysfunctions in the signaling pathway that occur in the formation of the vascular network in endothelial cells will be greatly improved. Consequently, better therapeutic approaches to treat the abnormal angiogenesis of these patients could be developed.

\section{Conflict of Interests}

The authors declare that they have no competing interests.

\section{Acknowledgments}

The authors are grateful to the patients and their families for their participation in this study. They would also like to address special thanks to Nathalie Ruiz-Pallares, Department of Genetics, CHRU, Montpellier, France. This research was supported by the Hubert Curien Partnership (PHC Tassili 10MDU794) and grants from the Ministry of Foreign and European Affairs (Ministère des Affaires Étrangères et Européennes, MAEE) and the Ministry of Higher Education and Research of Algeria (Ministère Algérien de l'Enseignement Supérieur et de la Recherche Scientifique, MESRS).

\section{References}

[1] R. G. Elluru, "Cutaneous vascular lesions," Facial Plastic Surgery Clinics of North America, vol. 21, no. 1, pp. 111-126, 2013.

[2] O. Enjolras, "Hemangiomes," in Atlas des Hémangiomes et Malformations Vasculaires Superficielles, O. Enjolras, M. C. Riche, J.
B. Mulliken, and J. J. Merland, Eds., pp. 17-54, Medsi McGrawHill, Paris, France, 1990.

[3] F. Lemarchand-Venencien, "Classification of angiomas: hemangiomas and superficial vascular malformations," Revue du Praticien, vol. 42, no. 16, pp. 1998-2004, 1992.

[4] D. A. Marchuk, S. Srinivasan, T. L. Squire, and J. S. Zawistowski, "Vascular morphogenesis: tales of two syndromes," Human Molecular Genetics, vol. 12, no. 1, pp. R97-R112, 2003.

[5] J. Murthy, "Vascular anomalies," Indian Journal of Plastic Surgery, vol. 38, no. 1, pp. 56-62, 2005.

[6] G. T. Richter and A. B. Friedman, "Hemangiomas and vascular malformations: current theory and management," International Journal of Pediatrics, vol. 2012, Article ID 645678, 10 pages, 2012.

[7] A. Di Giovanni and L. Revelli, "Venous angiodysplasias with endoral manifestation. The problems of therapy," Minerva stomatologica, vol. 45, no. 3, pp. 113-119, 1996.

[8] L. B. Kaban and J. B. Mulliken, "Vascular anomalies of the maxillofacial region," Journal of Oral and Maxillofacial Surgery, vol. 44, no. 3, pp. 203-213, 1986.

[9] J. A. Werner, A. A. Dünne, B. J. Folz et al., "Current concepts in the classification, diagnosis and treatment of hemangiomas and vascular malformations of the head and neck," European Archives of Oto-Rhino-Laryngology, vol. 258, no. 3, pp. 141-149, 2001.

[10] D. Herbreteau, O. Enjolras, and M. C. Riché, "Superficial venous malformations," Revue du Praticien, vol. 42, no. 16, pp. 20252030, 1992.

[11] M. Vikkula, L. M. Boon, K. L. Carraway III et al., "Vascular dysmorphogenesis caused by an activating mutation in the receptor tyrosine kinase TIE2," Cell, vol. 87, no. 7, pp. 1181-1190, 1996.

[12] L. M. Boon, J. B. Mulliken, M. Vikkula et al., "Assignment of a locus for dominantly inherited venous malformations to chromosome 9p," Human Molecular Genetics, vol. 3, no. 9, pp. 15831587, 1994.

[13] V. Wouters, N. Limaye, M. Uebelhoer et al., "Hereditary cutaneomucosal venous malformations are caused by TIE2 mutations with widely variable hyper-phosphorylating effects," European Journal of Human Genetics, vol. 18, no. 4, pp. 414-420, 2010.

[14] N. Limaye, L. M. Boon, and M. Vikkula, "From germline towards somatic mutations in the pathophysiology of vascular anomalies," Human Molecular Genetics, vol. 18, no. 1, pp. R65R74, 2009. 
[15] B. Sari, M. Aribi, and B. Saari, "Effect of endogamy and consanguinity on the development of labial venous malformations in area of Tlemcen (West Algeria)," The Open Genomics Journal, vol. 1, pp. 1-5, 2008.

[16] O. Enjolras, M. C. Riche, and J. J. Merland, "Superficial arterial and venous malformations: clinical features and complementary investigations," Annales de Chirurgie Plastique et Esthetique, vol. 36, no. 4, pp. 271-278, 1991.

[17] S. Rozen and H. Skaletsky, "Primer3 on the WWW for general users and for biologist programmers," Methods in Molecular Biology, vol. 132, pp. 365-386, 2000.

[18] T. Hubbard, D. Barker, E. Birney et al., "The Ensembl genome database project," Nucleic Acids Research, vol. 30, no. 1, pp. 3841, 2002.

[19] D. J. Dumont, T. P. Yamaguchi, R. A. Conlon, J. Rossant, and M. L. Breitman, "Tek, a novel tyrosine kinase gene located on mouse chromosome 4, is expressed in endothelial cells and their presumptive precursors," Oncogene, vol. 7, no. 8, pp. 1471-1480, 1992.

[20] H. Schnurch and W. Risau, "Expression of tie-2, a member of a novel family of receptor tyrosine kinases, in the endothelial cell lineage," Development, vol. 119, no. 3, pp. 957-968, 1993.

[21] T. N. Sato, Y. Qin, C. A. Kozak, and K. L. Audus, “Tie-1 and tie-2 define another class of putative receptor tyrosine kinase genes expressed in early embryonic vascular system," Proceedings of the National Academy of Sciences of the United States of America, vol. 90, no. 24, pp. 9355-9358, 1993.

[22] D. J. Dumont, G. Gradwohl, G. H. Fong et al., "Dominantnegative and targeted null mutations in the endothelial receptor tyrosine kinase, tek, reveal a critical role in vasculogenesis of the embryo," Genes and Development, vol. 8, no. 16, pp. 1897-1909, 1994.

[23] D. J. Dumont, G. H. Fong, M. C. Puri, G. Gradwohl, K. Alitalo, and M. L. Breitman, "Vascularization of the mouse embryo: a study of flk-1, tek, tie, and vascular endothelial growth factor expression during development," Developmental Dynamics, vol. 203, no. 1, pp. 80-92, 1995.

[24] T. N. Sato, Y. Tozawa, U. Deutsch et al., "Distinct roles of the receptor tyrosine kinases Tie-1 and Tie-2 in blood vessel formation," Nature, vol. 376, no. 6535, pp. 70-74, 1995.

[25] C. Suri, P. F. Jones, S. Patan et al., "Requisite role of angiopoietin1, a ligand for the TIE2 receptor, during embryonic angiogenesis," Cell, vol. 87, no. 7, pp. 1171-1180, 1996.

[26] J. Partanen and D. J. Dumont, "Functions of Tiel and Tie2 receptor tyrosine kinases in vascular development," Current Topics in Microbiology and Immunology, vol. 237, pp. 159-172, 1999.

[27] N. Jones, K. Iljin, D. J. Dumont, and K. Alitalo, “Tie receptors: new modulators of angiogenic and lymphangiogenic responses," Nature Reviews Molecular Cell Biology, vol. 2, no. 4, pp. 257-267, 2001.

[28] L. Eklund and B. R. Olsen, "Tie receptors and their angiopoietin ligands are context-dependent regulators of vascular remodeling," Experimental Cell Research, vol. 312, no. 5, pp. 630-641, 2006.

[29] P. C. Maisonpierre, C. Suri, P. F. Jones et al., "Angiopoietin-2, a natural antagonist for Tie2 that disrupts in vivo angiogenesis," Science, vol. 277, no. 5322, pp. 55-60, 1997.

[30] S. Loughna and T. N. Sato, "Angiopoietin and Tie signaling pathways in vascular development," Matrix Biology, vol. 20, no. 5-6, pp. 319-325, 2001.
[31] P. Saharinen, K. Kerkelä, N. Ekman et al., "Multiple angiopoietin recombinant proteins activate the Tiel receptor tyrosine kinase and promote its interaction with Tie2," Journal of Cell Biology, vol. 169, no. 2, pp. 239-243, 2005.

[32] H. T. Yuan, S. Venkatesha, B. Chan et al., "Activation of the orphan endothelial receptor Tiel modifies Tie2-mediated intracellular signaling and cell survival," FASEB Journal, vol. 21, no. 12, pp. 3171-3183, 2007.

[33] D. M. Valenzuela, J. A. Griffiths, J. Rojas et al., "Angiopoietins 3 and 4: diverging gene counterparts in mice and humans," Proceedings of the National Academy of Sciences of the United States of America, vol. 96, no. 5, pp. 1904-1909, 1999.

[34] I. Cascone, L. Napione, F. Maniero, G. Serini, and F. Bussolino, "Stable interaction between $\alpha 5 \beta 1$ integrin and Tie2 tyrosine kinase receptor regulates endothelial cell response to Ang-1," Journal of Cell Biology, vol. 170, no. 6, pp. 993-1004, 2005.

[35] K. L. Kim, I. S. Shin, J. M. Kim et al., "Interaction between Tie receptors modulates angiogenic activity of angiopoietin 2 in endothelial progenitor cells," Cardiovascular Research, vol. 72, no. 3, pp. 394-402, 2006.

[36] G. Fachinger, U. Deutsch, and W. Risau, "Functional interaction of vascular endothelial-protein-tyrosine phosphatase with the Angiopoietin receptor Tie-2," Oncogene, vol. 18, no. 43, pp. 5948-5953, 1999.

[37] M. G. Dominguez, V. C. Hughes, L. Pan et al., "Vascular endothelial tyrosine phosphatase (VE-PTP)-null mice undergo vasculogenesis but die embyronically because of defects in angiogenesis," Proceedings of the National Academy of Sciences of the United States of America, vol. 104, no. 9, pp. 3243-3248, 2007.

[38] H. Kidoya, M. Ueno, Y. Yamada et al., "Spatial and temporal role of the apelin/APJ system in the caliber size regulation of blood vessels during angiogenesis," EMBO Journal, vol. 27, no. 3, pp. 522-534, 2008. 

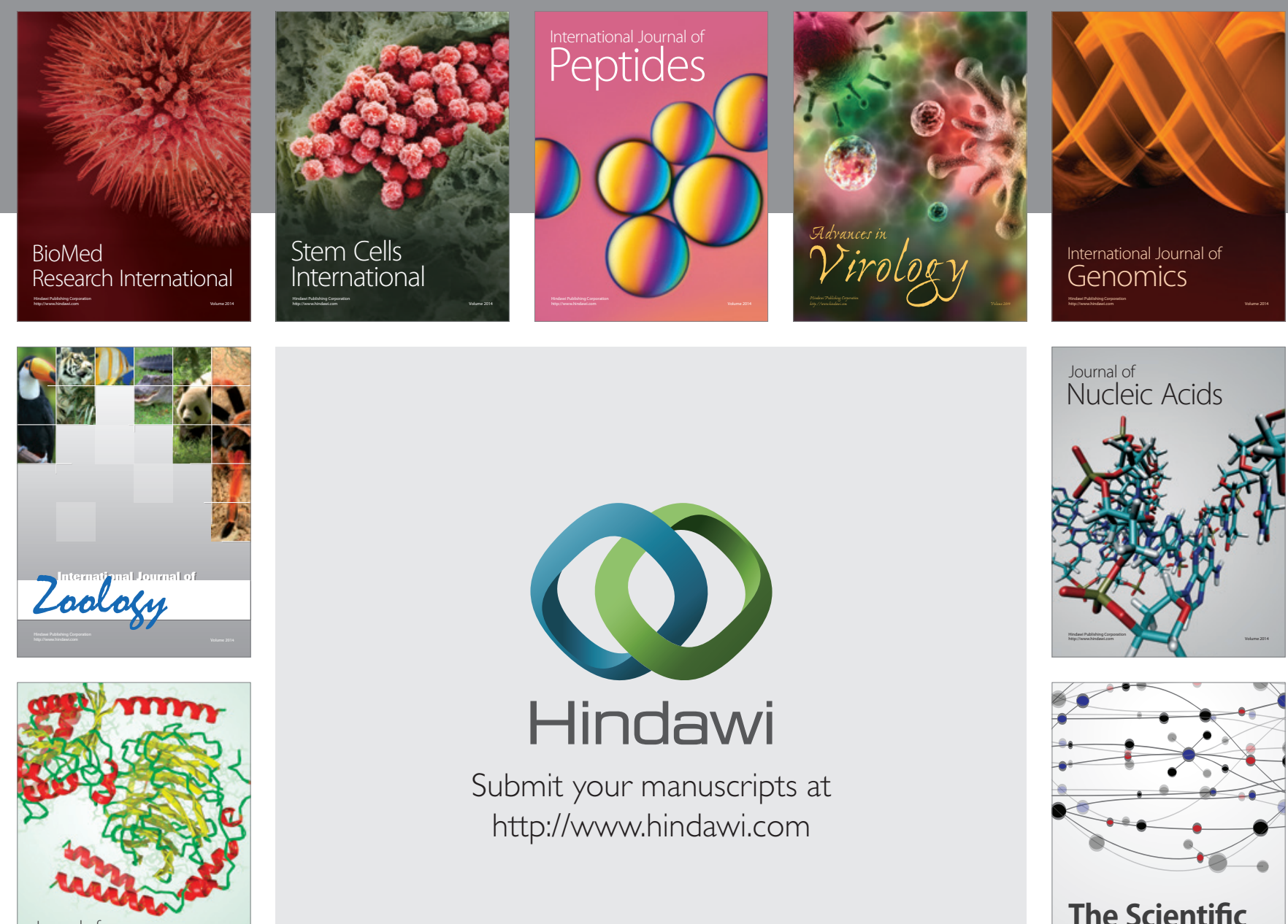

Submit your manuscripts at

http://www.hindawi.com

Journal of
Signal Transduction
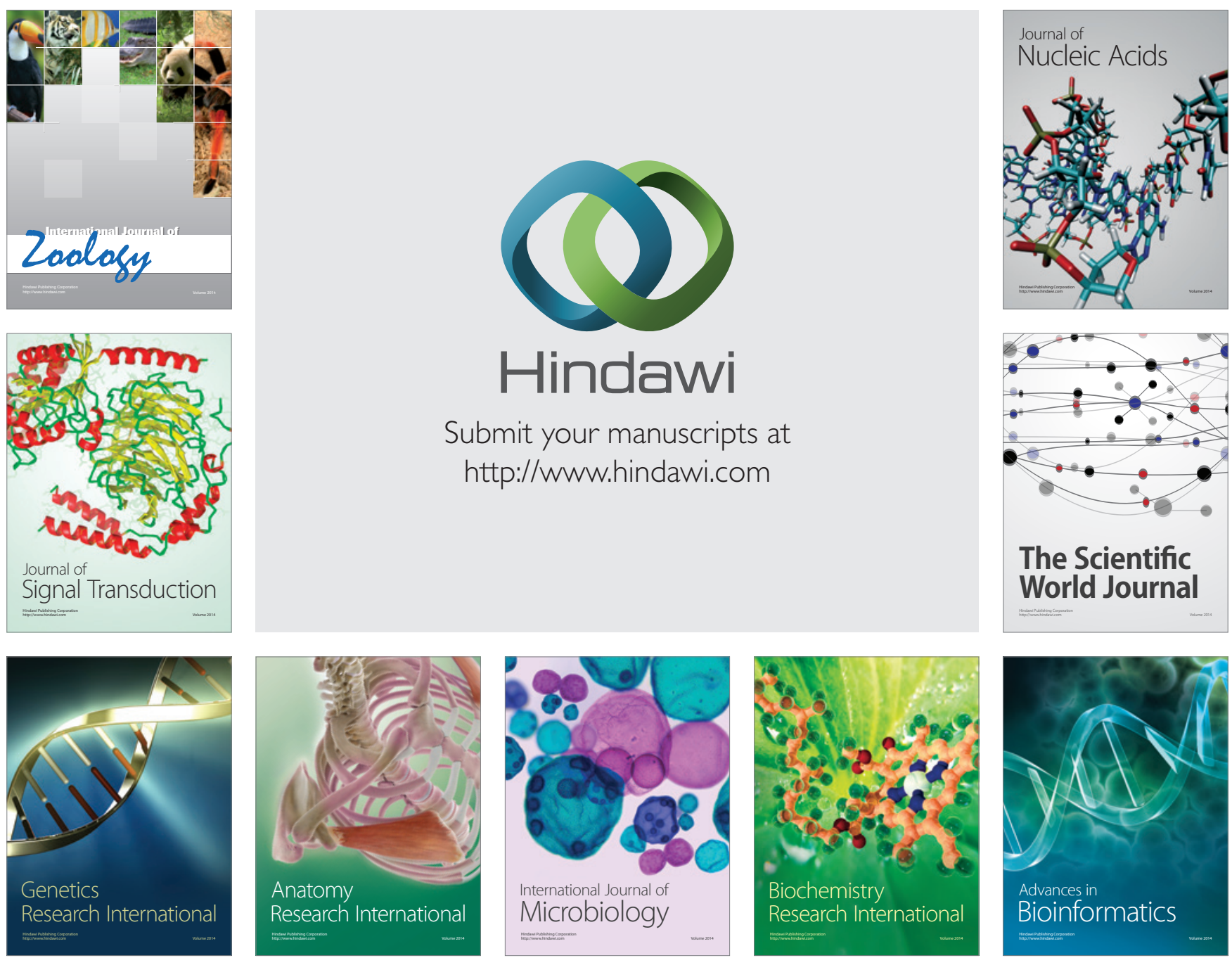

The Scientific World Journal
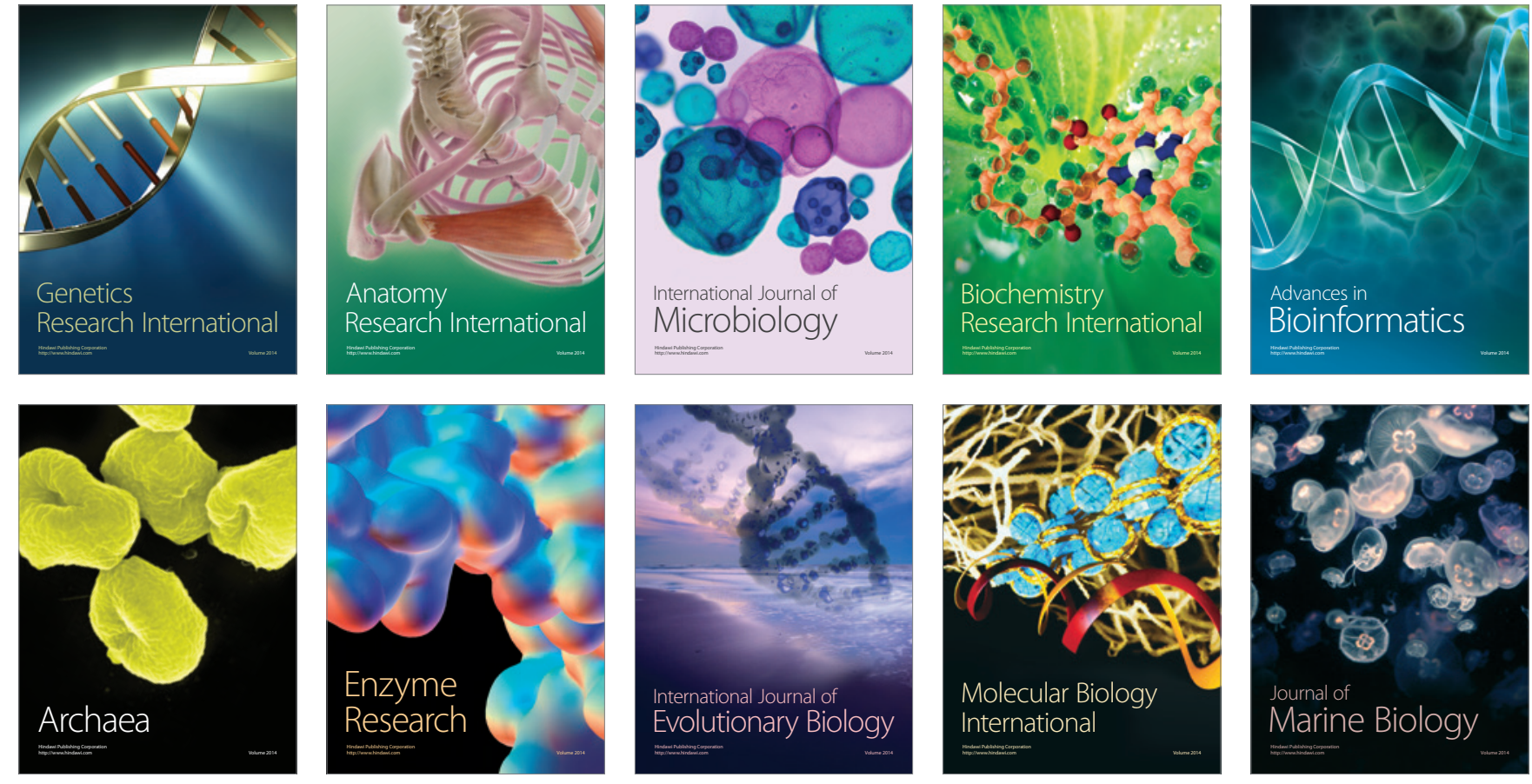